\title{
Whole small fish as a rich calcium source
}

\author{
Torben Larsen ${ }^{1}$, Shakuntala H. Thilsted ${ }^{2 *}$, Katja Kongsbak ${ }^{2}$ and Marianne Hansen ${ }^{2}$ \\ ${ }^{1}$ Department of Animal Health and Welfare, Research Center Foulum, Danish Institute of Agricultural Sciences, \\ PO Box 50, 8830 Tjele, Denmark \\ ${ }^{2}$ Research Department of Human Nutrition, The Royal Veterinary and Agricultural University, Rolighedsvej 30, \\ 1958 Frederiksberg C, Denmark
}

(Received 8 February 1999 - Revised 14 July 1999 - Accepted 16 August 1999)

\begin{abstract}
The present rat balance study investigated $\mathrm{Ca}$ availability from the whole indigenous small fish species, mola (Amblypharyngodon mola) from Bangladesh and from skimmed milk. Four groups of six young male rats each were fed ad libitum with diets containing either small fish or milk, at 100 or $160 \mathrm{~g}$ crude protein/kg diet dry matter. The study was conducted for $28 \mathrm{~d}$ and faeces and urine samples were collected in two balance periods: days $8-14$ and $22-28$. The $\mathrm{Ca}$ and $\mathrm{N}$ contents of the diets, faeces and urine were analysed. $\mathrm{Ca}$ intake, fractional $\mathrm{Ca}$ absorption and $\mathrm{Ca}$ retention in relation to $\mathrm{N}$ retention were measured. Digestibility and protein utilization of the experimental diets, weight gain of the rats, femur bone weight and mineral composition as well as bone alkaline phosphatase activity were also determined. It was concluded from the values of these variables that $\mathrm{Ca}$ from small fish with bones was available and appeared to be a useful $\mathrm{Ca}$ source in rats, though perhaps not as available as Ca from milk. This study suggests that small fish with bones may be an important source of $\mathrm{Ca}$ in human diets. Promotion of the production and consumption of small fish in population groups with low intakes of milk and milk products should therefore be encouraged.
\end{abstract}

Calcium availability: Fish: Milk: Balance study

Low Ca intakes are reported in many low-income countries, where milk and milk products make up only a small part of the diet (Food and Agriculture Organization, 1974; Ahmad \& Hassan, 1983). In view of the importance of $\mathrm{Ca}$ in human nutrition and especially the substantial quantities required for fetal growth, milk production and growth in young children, the intake of $\mathrm{Ca}$ and the availability of $\mathrm{Ca}$ from foods are both of interest. Whole small fish with bones are an extremely Ca-rich food (Gopalan et al. 1987; DarntonHill et al. 1988; West \& Poortvliet, 1993). In many population groups in low-income countries, small fish play an important role in the everyday diet since they are often used in sauces and curries, which are eaten with the main staple. However, there is very little information on the availability of $\mathrm{Ca}$ from bones and none on that from the bones of small fish. The aim of the present study was to examine the availability of $\mathrm{Ca}$ from an indigenous small fish species, mola (Amblypharyngodon mola) which is commonly consumed in Bangladesh, as well as from milk in a rat balance study. $\mathrm{Ca}$ intake, fractional $\mathrm{Ca}$ absorption and $\mathrm{Ca}$ retention in relation to $\mathrm{N}$ retention were measured. Digestibility and protein utilization of the experimental diets, weight gain of the rats, femur bone weight and mineral composition as well as bone alkaline phosphatase (AP) activity were also determined.

\section{Materials and methods}

\section{Experimental animals and diets}

Twenty-four male Wistar rats, 3-4 weeks old with an average weight of $66 \mathrm{~g}$ were used in the experiment. Four experimental diets were formulated, two based on whole small fish and two on skimmed milk powder. The small fish, mola, were bought at the local market in Mymensingh district, Bangladesh, cleaned with ash and the gut content was pressed out. The fish were washed, dried in the sun for $4 \mathrm{~d}$ and homogenized before use. The skimmed milk powder was a commercial dried product provided by MD Foods Ingredients, Videbaek, Denmark. Each of the two foodstuffs was mixed with $\mathrm{N}$-free maize starch to give isonitrogenous diets with 100 and $160 \mathrm{~g}$ crude protein $(\mathrm{CP}) / \mathrm{kg}$ diet DM (CP assessed as $\mathrm{N} \times 6 \cdot 25$ ). Isonitrogenous diets were formulated to ensure equal intakes of protein, thereby eliminating the effect of different protein intakes on growth in the rats. Diets with high $(160 \mathrm{~g} / \mathrm{kg})$ and low $(100 \mathrm{~g} / \mathrm{kg})$ protein levels were 
used so that the growth rate in the rats could be related to protein utilization. Vitamin and mineral mixtures, excluding $\mathrm{Ca}$ and $\mathrm{Zn}$, were added to the diets. The compositions of the diets are presented in Table 1. The chemical compositions of the two foodstuffs, N-free maize starch and the four experimental diets are shown in Table 2. The fish contained $680 \mathrm{~g}$ protein $/ \mathrm{kg} \mathrm{DM}$ and $49.6 \mathrm{~g} \mathrm{Ca} / \mathrm{kg} \mathrm{DM}$. The skimmed milk powder contained less protein and $\mathrm{Ca}$ than the fish, $400 \mathrm{~g}$ protein $/ \mathrm{kg} \mathrm{DM}$ and $13 \cdot 2 \mathrm{~g} \mathrm{Ca} / \mathrm{kg} \mathrm{DM}$.

\section{Experimental design}

The rats were divided into six blocks, each block with four rats of similar weights. In each block, the four different diets were randomized. Each rat was placed in a separate metabolic cage and redistilled water and feed were given $a d$ libitum. The experiment was conducted for $28 \mathrm{~d}$, with an initial adaptation period of $7 \mathrm{~d}$ and two balance periods of $7 \mathrm{~d}$ each (days 8-14 and 22-28). The weights of the rats were recorded on days $1,8,14,22$ and 28 (final weight). In each balance period, feed given at the start and feed left over at the end were measured and the difference was recorded as the feed intake. Faeces and urine were collected separately in two balance periods, days 8-14 and days 22-28. In each balance period, faeces were collected daily, pooled, freezedried and ground. In each balance period, urine was preserved with dilute $\mathrm{HCl}$. On the last day of the experiment (day 28), the rats were anaesthetized, blood was drawn from the heart into cooled heparinized tubes and plasma was separated and stored frozen. The femur bones were removed, freed from connective tissue and freeze-dried.

All materials and utensils, including the cages, were washed with dilute $\mathrm{HNO}_{3}$ and rinsed thoroughly with distilled water before use. The experimental procedure has been described in detail by Larsen \& Sandström (1992).

\section{Analytical methods}

The $\mathrm{N}$ contents of the foodstuffs, $\mathrm{N}$-free maize starch, diets, faeces and urine from each balance period were determined by the automatic Kjeldahl procedure (Kjel-Foss 16200). The contents of $\mathrm{Ca}, \mathrm{Mg}, \mathrm{Fe}, \mathrm{Zn}, \mathrm{Cu}$ and $\mathrm{Mn}$ were measured by atomic absorption spectrophotometry (PU 9400 X, Philips Scientific, Cambridge, Cambs, UK). Spectrophotometry measurements were calibrated using commercial standards (Tritisol, E. Merck, Darmstadt, Germany). The standard curves were controlled using chloride solutions of the metals. Relative standard deviations for the determination of $\mathrm{Ca}$ and $\mathrm{Fe}$ ranged from 0.4 to $1.3 \%$. $\mathrm{P}$ was analysed by the vanadomolybdate procedure (Stuffins, 1967). Ash, Ca and $\mathrm{P}$ contents of the femur bones from each rat were determined. Total AP in plasma was determined according to Bowers \& McComb (1975) and bone AP was assessed according to Moss (1982).

Table 1. Composition of experimental diets (g DM/kg diet DM)

\begin{tabular}{|c|c|c|c|c|}
\hline \multirow[b]{2}{*}{ Diet code ... } & \multicolumn{2}{|c|}{ Fish diet } & \multicolumn{2}{|c|}{ Milk diet } \\
\hline & $\begin{array}{c}100 \mathrm{~g} \mathrm{CP} / \mathrm{kg} \\
(\mathrm{FD} 100)\end{array}$ & $\begin{array}{c}160 \mathrm{~g} \mathrm{CP} / \mathrm{kg} \\
(\text { FD160) }\end{array}$ & $\begin{array}{c}100 \mathrm{~g} \mathrm{CP} / \mathrm{kg} \\
(\mathrm{MD} 100)\end{array}$ & $\begin{array}{c}160 \mathrm{~g} \mathrm{CP} / \mathrm{kg} \\
\text { (MD160) }\end{array}$ \\
\hline Small fish, sun dried & 147 & 236 & - & - \\
\hline Skimmed milk powder & - & - & 251 & 401 \\
\hline $\mathrm{N}$-free maize starch & 829 & 740 & 725 & 575 \\
\hline Mineral mixture (excluding $\mathrm{Ca})^{*}$ & 8.2 & 8.2 & 8.2 & 8.2 \\
\hline Vitamin mixture & $16 \cdot 0$ & $16 \cdot 0$ & $16 \cdot 0$ & $16 \cdot 0$ \\
\hline \multicolumn{5}{|c|}{ 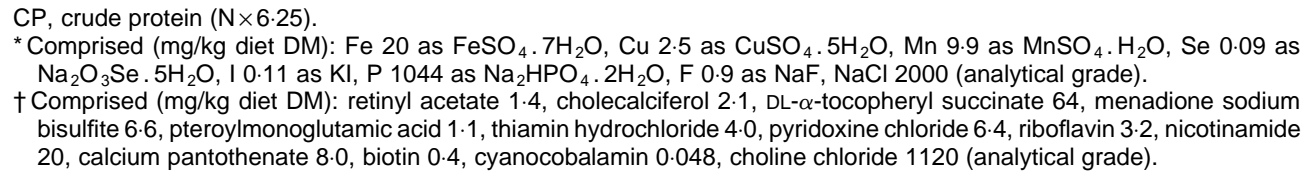 } \\
\hline
\end{tabular}

Table 2. Nitrogen, ash and mineral content (/kg DM) of small fish, skimmed milk powder, nitrogen-free maize starch and the four experimental diets

\begin{tabular}{|c|c|c|c|c|c|c|c|}
\hline & \multirow{2}{*}{$\begin{array}{c}\text { Small } \\
\text { fish }\end{array}$} & \multirow{2}{*}{$\begin{array}{c}\text { Skimmed } \\
\text { milk } \\
\text { powder }\end{array}$} & \multirow{2}{*}{$\begin{array}{l}\text { N-free } \\
\text { maize } \\
\text { starch }\end{array}$} & \multicolumn{4}{|c|}{ Experimental diets } \\
\hline & & & & FD100 & FD160 & MD100 & MD160 \\
\hline Nitrogen (g) & 109 & 63.8 & $2 \cdot 0$ & $15 \cdot 1$ & $24 \cdot 8$ & $15 \cdot 4$ & $24 \cdot 3$ \\
\hline Ash (g) & 170 & 84 & 0.8 & 31 & 45 & 28 & 39 \\
\hline Calcium $(\mathrm{g})^{*}$ & $49 \cdot 6$ & $13 \cdot 2$ & 0.1 & 6.9 & $10 \cdot 6$ & 3.3 & $5 \cdot 3$ \\
\hline Phosphorus (g) & $27 \cdot 7$ & $10 \cdot 4$ & 0.1 & $5 \cdot 2$ & $7 \cdot 2$ & $3 \cdot 7$ & $5 \cdot 1$ \\
\hline Magnesium (g) & $2 \cdot 1$ & $1 \cdot 3$ & 0.04 & 0.3 & 0.5 & 0.3 & 0.5 \\
\hline Iron (mg) & 606 & 7 & 7 & 110 & 156 & 25 & 25 \\
\hline Zinc (mg) & 672 & 49 & 2 & 103 & 150 & 14 & 24 \\
\hline Manganese (mg) & 73 & - & - & 26 & 30 & 13 & 13 \\
\hline Copper (mg) & 10 & 2 & 2 & 5 & 6 & 7 & 7 \\
\hline
\end{tabular}

FD100, fish diet with $100 \mathrm{~g}$ crude protein (CP)/kg; FD160, fish diet with $160 \mathrm{~g} \mathrm{CP} / \mathrm{kg}$; MD100, milk diet with $100 \mathrm{~g} \mathrm{CP} / \mathrm{kg}$; MD160, milk diet with $160 \mathrm{~g} \mathrm{CP} / \mathrm{kg}$.

${ }^{*} \mathrm{Ca}$ in diets stemmed mainly from small fish or skimmed milk. 


\section{Calculation and presentation of results}

Apparent $\mathrm{Ca}$ absorption $(\mathrm{mg} \mathrm{Ca} / \mathrm{d}$ ) was calculated as $\mathrm{Ca}$ intake minus $\mathrm{Ca}$ excreted in faeces. Ca retention $(\mathrm{mg} \mathrm{Ca} / \mathrm{d})$ was calculated as $\mathrm{Ca}$ intake minus $\mathrm{Ca}$ excreted in faeces and urine. $\mathrm{N}$ absorption and retention were calculated similarly. $\mathrm{Ca}$ retention in relation to $\mathrm{N}$ retention was expressed as $\mathrm{mg}$ $\mathrm{Ca} / \mathrm{mg} \mathrm{N}$. The fractional $\mathrm{Ca}$ absorption (mg Ca/mg Ca) was the apparent $\mathrm{Ca}$ absorption in relation to $\mathrm{Ca}$ intake. Apparent DM digestibility (g DM/g DM) was DM digested (DM intake-DM faeces) in relation to DM intake. Apparent organic matter (OM) digestibility (g OM/g OM) was calculated similarly. Weight gain in rats was the change in weight from day 1 to day 28 .

The mineral $(\mathrm{Ca}$ or $\mathrm{P})$ content in ash of the femur bone was expressed as $\mathrm{g}$ mineral/kg ash. Bone AP activity (IU/1 plasma) was assessed as the difference in total AP activity in blood plasma before and after temperature inhibition at $56^{\circ}$ for $6 \mathrm{~min}$.

\section{Statistical analysis}

Values are expressed as least square means and standard errors $(\mathrm{SE}=$ root mean square error). Least square means were used because there was one missing value for faeces collected in the first balance period from one rat on the milk diet at the $160 \mathrm{~g}$ protein $/ \mathrm{kg}$ level. A complete randomized block design was used. Statistical analyses of all data except data for femur bones and bone AP were done using a splitplot model with blocks: foodstuff (fish, milk) and protein (100 g CP/kg, $160 \mathrm{~g} \mathrm{CP} / \mathrm{kg}$ ) as main plots, time (days 8-14, days 22-28) as sub-plot and blocks (1-6) which were based on initial live weights of the experimental animals. All values expressed were averages of the measurements in the first balance period ( $n 5$ or 6 ) and the second balance period $(n 6)$. Statistical analysis of data for femur bones and bone AP was done as a two-way ANOVA: foodstuff (fish, milk) and protein $(100 \mathrm{~g} \mathrm{CP} / \mathrm{kg}, 160 \mathrm{~g} \mathrm{CP} / \mathrm{kg})$ with blocks $(1-6)(n 6)$. The level of probability used to assess statistical significance was 0.05. Non-significant interactions were omitted from the models. Least significant differences $\left(\mathrm{LSD}_{0.95}\right)$ were calculated to compare least square means within significant interactions. The Pearson correlation coefficients, $r$, were estimated for weight gain and $\mathrm{N}$ retention. All computations were carried out with SAS/ Windows (Statistical Analysis Systems, version 6.11, 1996) software (SAS Institute, Inc., Cary, NC, USA).

\section{Results}

\section{Protein and calcium contents in the diets}

There was proportionally less fish in the fish diets than milk in the milk diets (Table 1), as the protein content of the fish was higher than that of milk and isonitrogenous diets were formulated (Table 2). Ca in the diets stemmed entirely from fish or milk. At $100 \mathrm{~g}$ protein $/ \mathrm{kg}$, the Ca contents were 6.9 and $3.3 \mathrm{~g} \mathrm{Ca} / \mathrm{kg} \mathrm{DM}$ and at $160 \mathrm{~g}$ protein $/ \mathrm{kg}, 10 \cdot 6$ and $5.3 \mathrm{~g}$ $\mathrm{Ca} / \mathrm{kg} \mathrm{DM}$ for the fish and milk diets respectively. The fish diets contained about twice the amount of $\mathrm{Ca}$ as the milk diets and the diets with $160 \mathrm{~g}$ protein $/ \mathrm{kg}$ contained 1.6 times more $\mathrm{Ca}$ than the $100 \mathrm{~g}$ protein $/ \mathrm{kg}$ diets (Table 2).

\section{Diet digestibility, protein utilization and growth of rats}

Table 3 shows DM and OM intakes and digestibilities in the rats. The average $\mathrm{DM}$ and $\mathrm{OM}$ intakes were similar for all diets and were 13.6 (SE 1.4) g DM/d and 13.1 (SE 1.3) g $\mathrm{OM} / \mathrm{d}$. Apparent DM digestibility of the diets was significantly affected by the foodstuff, with milk giving higher values than fish $(P<0 \cdot 05)$. Apparent DM digestibility of milk diets was not affected by the protein level, and was on average 0.939 (SE 0.006) g DM/g DM. In the fish diets, there was a significant difference in apparent DM digestibility between the two protein levels $(P<0.05)$. Apparent OM digestibility was significantly higher in the milk diets, on average $0.941 \mathrm{~g} \mathrm{OM} / \mathrm{g}$ OM, compared with the fish diets, 0.917 (SE 0.006) $(P<0.0001)$ and was not affected by the protein level.

$\mathrm{N}$ intakes were 224 and 374 (SE 28) $\mathrm{mg} \mathrm{N} / \mathrm{d}$ in rats on the fish diets and 218 and 325 (SE 28) $\mathrm{mg} \mathrm{N} / \mathrm{d}$ in rats on the milk diets, at 100 and $160 \mathrm{~g}$ protein $/ \mathrm{kg}$ levels respectively. $\mathrm{N}$ intake was significantly higher for fish than for milk $(P<0.05)$ and at the $160 \mathrm{~g}$ protein $/ \mathrm{kg}$ level compared with $100 \mathrm{~g} / \mathrm{kg}(P<0 \cdot 0001)$. Apparent $\mathrm{N}$ absorption and $\mathrm{N}$ retention were not affected by the foodstuff but by the protein level $(P<0.0001)$ in the diets. Apparent $\mathrm{N}$ absorption

Table 3. DM intake, DM digestibility, organic matter (OM) intake and OM digestibility in rats fed on diets containing either small fish or milk at two different protein levels*

(Least square means with their standard errors for eleven or twelve rats)

\begin{tabular}{|c|c|c|c|c|c|c|c|c|}
\hline \multirow[b]{2}{*}{ Protein level ... } & \multicolumn{2}{|c|}{$\begin{array}{l}\text { DM intake } \\
\text { (g DM/d) }\end{array}$} & \multicolumn{2}{|c|}{$\begin{array}{c}\text { DM digestibility } † \\
\text { (g DM/g DM) }\end{array}$} & \multicolumn{2}{|c|}{$\begin{array}{l}\text { OM intake } \\
(\mathrm{g} \mathrm{OM} / \mathrm{d})\end{array}$} & \multicolumn{2}{|c|}{$\begin{array}{l}\text { OM digestibility } \\
\text { (g OM/g OM) }\end{array}$} \\
\hline & $100 \mathrm{~g} \mathrm{CP} / \mathrm{kg}$ & $160 \mathrm{~g} \mathrm{CP} / \mathrm{kg}$ & $100 \mathrm{~g} \mathrm{CP} / \mathrm{kg}$ & $160 \mathrm{~g} \mathrm{CP} / \mathrm{kg}$ & $100 \mathrm{~g} \mathrm{CP} / \mathrm{kg}$ & $160 \mathrm{~g} \mathrm{CP} / \mathrm{kg}$ & $100 \mathrm{~g} \mathrm{CP} / \mathrm{kg}$ & $160 \mathrm{~g} \mathrm{CP} / \mathrm{kg}$ \\
\hline $\begin{array}{l}\text { Fish } \\
\text { Milk }\end{array}$ & $\begin{array}{l}14 \cdot 0 \\
13 \cdot 5\end{array}$ & $\begin{array}{l}14 \cdot 3 \\
12 \cdot 7\end{array}$ & $\begin{array}{l}0.906^{b} \\
0.937^{c}\end{array}$ & $\begin{array}{l}0.896^{\mathrm{a}} \\
0.940^{\mathrm{c}}\end{array}$ & $\begin{array}{l}13 \cdot 6 \\
13 \cdot 1\end{array}$ & $\begin{array}{l}13 \cdot 6 \\
12 \cdot 2\end{array}$ & $\begin{array}{l}0.918^{\mathrm{a}} \\
0.938^{\mathrm{b}}\end{array}$ & $\begin{array}{l}0.916^{a} \\
0.943^{b}\end{array}$ \\
\hline SE & \multicolumn{2}{|c|}{1.4} & \multicolumn{2}{|c|}{0.006} & \multicolumn{2}{|c|}{1.3} & \multicolumn{2}{|c|}{0.006} \\
\hline
\end{tabular}

$\mathrm{CP}$, crude protein $(\mathrm{N} \times 6 \cdot 25)$.

$a, b, c$ Least square mean values within the variable not sharing a common subscript letter were significantly different, $P<0.05$.

* For details of diets and procedures, see Tables 1 and 2 and pp. 191-193.

$\dagger$ There was a significant interaction between foodstuff and protein level, $P<0.01$.

$\ddagger$ Difference between foodstuffs was significant at $P<0.001$. 
Table 4. Calcium intake, fractional calcium absorption and calcium retention in relation to nitrogen retention in rats fed on diets containing either small fish or milk at two different protein levels*

(Least square means with their standard errors for twelve rats)

\begin{tabular}{|c|c|c|c|c|c|c|}
\hline \multirow[b]{2}{*}{ Protein level ... } & \multicolumn{2}{|c|}{$\begin{array}{l}\text { Ca intake } † \\
(\mathrm{mg} \mathrm{Ca} / \mathrm{d})\end{array}$} & \multicolumn{2}{|c|}{$\begin{array}{l}\text { Fractional Ca absorption } \ddagger \\
\qquad(\mathrm{mg} \mathrm{Ca} / \mathrm{mg} \mathrm{Ca})\end{array}$} & \multicolumn{2}{|c|}{$\begin{array}{l}\text { Ca retention } / \mathrm{N} \text { retentiont } \\
(\mathrm{mg} \mathrm{Ca} / \mathrm{mg} \mathrm{N})\end{array}$} \\
\hline & $100 \mathrm{~g} \mathrm{CP} / \mathrm{kg}$ & $160 \mathrm{~g} \mathrm{CP} / \mathrm{kg}$ & $100 \mathrm{~g} \mathrm{CP} / \mathrm{kg}$ & $160 \mathrm{~g} \mathrm{CP} / \mathrm{kg}$ & $100 \mathrm{~g} \mathrm{CP} / \mathrm{kg}$ & $160 \mathrm{~g} \mathrm{CP} / \mathrm{kg}$ \\
\hline $\begin{array}{l}\text { Fish } \\
\text { Milk }\end{array}$ & $\begin{array}{l}97 \cdot 2^{c} \\
44 \cdot 7^{a}\end{array}$ & $\begin{array}{r}151 \cdot 6^{\mathrm{d}} \\
67 \cdot 7^{\mathrm{b}}\end{array}$ & $\begin{array}{l}0.36^{b} \\
0.88^{d}\end{array}$ & $\begin{array}{l}0.25^{\mathrm{a}} \\
0.76^{\mathrm{c}}\end{array}$ & $\begin{array}{l}0.27^{b} \\
0.27^{b}\end{array}$ & $\begin{array}{l}0.20^{\mathrm{a}} \\
0.29^{\mathrm{b}}\end{array}$ \\
\hline SE & \multicolumn{2}{|c|}{8.3} & \multicolumn{2}{|c|}{0.03} & \multicolumn{2}{|c|}{0.06} \\
\hline
\end{tabular}

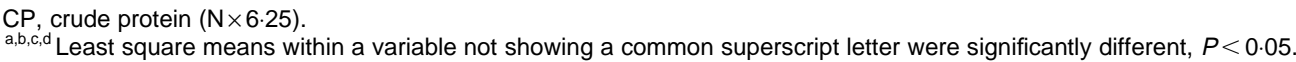

* For details of diets and procedures, see Tables 1 and 2 and pp. 191-193.

†There were significant interactions between foodstuff and protein level for $\mathrm{Ca}$ intake $(P<0.001)$ and $\mathrm{Ca}$ retention/ $\mathrm{N}$ retention $(P<0.01)$. $\ddagger$ There were significant differences between foodstuffs $(P<0.0001)$ and between levels of protein $(P<0.0001)$.

values were on average 188 and 309 (SE 26) $\mathrm{mg} \mathrm{N} / \mathrm{d}$ at 100 and $160 \mathrm{~g}$ protein/kg levels respectively. $\mathrm{N}$ retention values were on average 131 and 182 (SE 26) $\mathrm{mg} \mathrm{N} / \mathrm{d}$ at 100 and $160 \mathrm{~g}$ protein/kg levels respectively.

Weight gain in the rats during the whole experimental period was not affected by the foodstuff, however, protein level had a significant effect $(P<0 \cdot 01)$ on weight gain, with rats gaining on average $23 \%$ more weight at $160 \mathrm{~g}$ protein/ $\mathrm{kg}$ compared with the $100 \mathrm{~g}$ protein $/ \mathrm{kg}$ level. Weight gains were on average 4.0 and 5.0 (SE 0.3$) \mathrm{g} / \mathrm{d}$ at 100 and $160 \mathrm{~g}$ protein $/ \mathrm{kg}$ levels respectively. Weight gain in relation to $\mathrm{N}$ retention was on average 26.7 (SE 4.5) g/g N retention for all rats in the two balance periods and showed no effect of foodstuff or protein level.

\section{Calcium intake, fractional calcium absorption and calcium retention in relation to nitrogen retention}

Ca intake in rats fed on the fish diet was about twice as high as that in rats fed on milk at each protein level (Table 4). Ca intake was about 1.6 times higher at the $160 \mathrm{~g}$ compared with the $100 \mathrm{~g}$ protein $/ \mathrm{kg}$ level. Fractional $\mathrm{Ca}$ absorption was significantly lower $(P<0.0001)$ in rats fed on fish compared with milk and at $160 \mathrm{~g}$ compared with $100 \mathrm{~g}$ protein $/ \mathrm{kg}$ level $(P<0 \cdot 0001)$. Ca retention in relation to $\mathrm{N}$ retention was similar in rats fed on fish or milk at the $100 \mathrm{~g}$ protein $/ \mathrm{kg}$ level. However at $160 \mathrm{~g}$ protein $/ \mathrm{kg}, \mathrm{Ca}$ retention in relation to $\mathrm{N}$ retention was lower in rats fed on fish compared with those fed on milk.

\section{Calcium and phosphorus in femur bones}

The weights of femur bones were significantly higher in rats fed on milk compared with those fed on fish $(P<0.01)$ and at $160 \mathrm{~g}$ compared with $100 \mathrm{~g}$ protein/kg level $(P<0.0001)$ (Table 5). Values for femur bone weight in relation to final body weight (day 28) were on average 2.16 and 2.02 (SE $0.1) \mathrm{mg}$ bone $\mathrm{DM} / \mathrm{g}$ weight in rats fed on milk and fish respectively $(P<0.01)$, and were unaffected by protein level. Ash content in the femur bones was similar for all diets, on average 645 (SE 8) g ash/kg DM (Table 6). Ca and $\mathrm{P}$ contents in the femur bones were similar for all diets, on average 236 (SE 8) and 115 (SE 2) g/kg ash respectively. The $\mathrm{Ca}: \mathrm{P}$ values were similar for all diets, on average 1.58 (SE $0.05) \mathrm{mol} / \mathrm{mol}$.

\section{Bone alkaline phosphatase activity}

Bone AP activities were similar for all groups of rats, on average 130 (SE 33) IU/l plasma.

\section{Discussion}

This study shows that a diet based on sun-dried mola fish appears to be of good nutritional value in supporting growth

Table 5. Weight of femur bones and femur bone weight in relation to final body weight in rats fed on diets containing either small fish or milk at two different protein levels* (Least square mean values with their standard errors for six rats)

\begin{tabular}{|c|c|c|c|c|}
\hline \multirow[b]{2}{*}{ Protein level ... } & \multicolumn{2}{|c|}{$\begin{array}{l}\text { Weight of femur bonest } \\
\text { (g DM) }\end{array}$} & \multicolumn{2}{|c|}{$\begin{array}{l}\text { Femur bone wt/final body wtł } \\
\qquad(\mathrm{mg} \mathrm{DM} / \mathrm{g})\end{array}$} \\
\hline & $100 \mathrm{~g} \mathrm{CP} / \mathrm{kg}$ & $160 \mathrm{~g} \mathrm{CP} / \mathrm{kg}$ & $100 \mathrm{~g} \mathrm{CP} / \mathrm{kg}$ & $160 \mathrm{~g} \mathrm{CP} / \mathrm{kg}$ \\
\hline $\begin{array}{l}\text { Fish } \\
\text { Milk } \\
\text { SE }\end{array}$ & $\begin{array}{l}0.36^{a} \\
0.38^{b}\end{array}$ & $\begin{array}{l}0.41^{c} \\
0.45^{d}\end{array}$ & $\begin{array}{l}2 \cdot 06^{a} \\
2 \cdot 14^{b}\end{array}$ & $\begin{array}{l}1 \cdot 98^{\mathrm{a}} \\
2 \cdot 18^{\mathrm{b}}\end{array}$ \\
\hline $\begin{array}{l}\text { CP, crude protein } \\
\text { a,b,c,d Least square } \\
\quad P<0.05 \text {. } \\
\text { * For details of die } \\
\text { †There were sign } \\
\text { †There was a sig }\end{array}$ & $\begin{array}{l}\text { ithin a variable } \\
\text { cedures, see } \\
\text { erences betwe } \\
\text { fference betwe }\end{array}$ & $\begin{array}{l}\text { wing a commor } \\
\text { and } 2 \text { and pp. } \\
\text { stuffs }(P<0.01) \\
\text { oodstuffs }(P<0\end{array}$ & $\begin{array}{l}\text { cript letter were } \\
3 . \\
\text { tween protein le }\end{array}$ & $\begin{array}{l}\text { antly different, } \\
<0.0001)\end{array}$ \\
\hline
\end{tabular}


Table 6. Ash, calcium, phosphorus and calcium : phosphorus values in femur bones of rats fed on diets containing small fish or milk at two different protein levels*

(Least square mean values with their standard errors for six rats)

\begin{tabular}{|c|c|c|c|c|c|c|c|c|}
\hline \multirow[b]{2}{*}{ Protein level ... } & \multicolumn{2}{|c|}{$\begin{array}{l}\text { Ash in femur bones } \\
\text { (g ash/kg DM) }\end{array}$} & \multicolumn{2}{|c|}{$\begin{array}{l}\text { Ca in femur bones } \\
\text { (g Ca/kg ash) }\end{array}$} & \multicolumn{2}{|c|}{$\begin{array}{l}P \text { in femur bones } \\
(\mathrm{g} \mathrm{P} / \mathrm{kg} \text { ash })\end{array}$} & \multicolumn{2}{|c|}{$\begin{array}{l}\mathrm{Ca}: \mathrm{P} \text { in femur bones } \\
(\mathrm{mol} \mathrm{Ca} / \mathrm{mol} \mathrm{P})\end{array}$} \\
\hline & $100 \mathrm{~g} \mathrm{CP} / \mathrm{kg}$ & $160 \mathrm{~g} \mathrm{CP} / \mathrm{kg}$ & $100 \mathrm{~g} \mathrm{CP} / \mathrm{kg}$ & $160 \mathrm{~g} \mathrm{CP} / \mathrm{kg}$ & $100 \mathrm{~g} \mathrm{CP} / \mathrm{kg}$ & $160 \mathrm{~g} \mathrm{CP} / \mathrm{kg}$ & $100 \mathrm{~g} \mathrm{CP} / \mathrm{kg}$ & $160 \mathrm{~g} \mathrm{CP} / \mathrm{kg}$ \\
\hline $\begin{array}{l}\text { Fish } \\
\text { Milk }\end{array}$ & $\begin{array}{l}643 \\
645\end{array}$ & $\begin{array}{l}645 \\
649\end{array}$ & $\begin{array}{l}238 \\
238\end{array}$ & $\begin{array}{l}236 \\
232\end{array}$ & $\begin{array}{l}115 \\
116\end{array}$ & $\begin{array}{l}115 \\
116\end{array}$ & $\begin{array}{l}1.60 \\
1.59\end{array}$ & $\begin{array}{l}1.59 \\
1.55\end{array}$ \\
\hline SE & \multicolumn{2}{|c|}{8} & \multicolumn{2}{|c|}{8} & \multicolumn{2}{|c|}{2} & \multicolumn{2}{|c|}{0.05} \\
\hline
\end{tabular}

$\mathrm{CP}$, crude protein $(\mathrm{N} \times 6 \cdot 25)$.

${ }^{*}$ For details of diets and procedures, see Tables 1 and 2 and pp. 191-193.

in young rats. For all four experimental diets, digestibilities of DM and OM were high and high growth rates were achieved. The higher weight gain at $160 \mathrm{~g}$ protein $/ \mathrm{kg}$ compared with $100 \mathrm{~g}$ protein $/ \mathrm{kg}$ reflected a higher protein utilization at the higher protein level and suggested that protein was a limiting factor for growth in young fastgrowing rats on the low-protein diets. Fish protein showed a high biological value, comparable with that of milk, as shown by the similar values for apparent $\mathrm{N}$ absorption and $\mathrm{N}$ retention at each protein level. Weight gain in relation to $\mathrm{N}$ retention was similar in all rats. These results are comparable with those found previously in rats (Larsen, 1993) and young pigs (Larsen \& Poulsen, 1996). The close correlation ( $r$ 0.84-0.97, $P<0.001)$ between weight gain and $\mathrm{N}$ retention for each diet indicated that all rats gained proportionally the same amount of lean mass, indicated by $\mathrm{N}$ retention.

Since Ca intake from the fish diets was not similar to that from the milk diets, it was difficult to compare directly absolute $\mathrm{Ca}$ absorption from the two types of diets. $\mathrm{Ca}$ retention in relation to $\mathrm{N}$ retention was used as a measure of $\mathrm{Ca}$ retention, taking into account the different growth rates of the rats that may have occurred depending on the different compositions of the fish and milk diets. Although $\mathrm{Ca}$ intake from the fish diets was higher than from the milk diets, $\mathrm{Ca}$ retention in relation to $\mathrm{N}$ retention was similar for both the fish and milk diets at $100 \mathrm{~g}$ protein $/ \mathrm{kg}$, but lower for the fish diet than the milk diet at $160 \mathrm{~g}$ protein $/ \mathrm{kg}$. It is likely that $\mathrm{Ca}$ was less well absorbed from the fish diets than from the milk diets.

To our knowledge, no other studies have been published on Ca availability from small fish eaten with bones and only one human study on availability of $\mathrm{Ca}$ from bone per se. The study showed that the fractional $\mathrm{Ca}$ absorption in human subjects was $27.2 \%$ from calf bone powder and $26.7 \%$ from milk (Heaney et al. 1990). Ca absorption studies in human subjects are expensive and therefore only possible on a small scale. The rat model is useful for ranking $\mathrm{Ca}$ availability from different foods, though not necessarily providing absolute values (Weaver et al. 1987; Heaney et al. 1988).

The uptake of $\mathrm{Ca}$ across the intestinal mucosa may depend on the preceding ionization of the $\mathrm{Ca}$ compounds, since it has been shown that $\mathrm{Ca}$ is absorbed and transported as $\mathrm{Ca}^{++}$(Bronner, 1987; Wasserman \& Fulmer, 1989). Ca in small fish is found primarily in bones as the crystalline compound hydroxyapatite, which is insoluble at neutral $\mathrm{pH}$. However, the gastric acid medium in the stomach increases the solubility of hydroxyapatite (Allen, 1982). The lower Ca retention in relation to $\mathrm{N}$ retention found in the fish diets at 160 compared with $100 \mathrm{~g}$ protein $/ \mathrm{kg}$ fell in line with a lower ash digestibility which was deduced from the similar apparent OM digestibility but lower DM digestibility at $160 \mathrm{~g}$ protein $/ \mathrm{kg}$ (Table 3). The higher amount of fish in the diet with $160 \mathrm{~g}$ protein $/ \mathrm{kg}$ may change the levels of factors such as hydroxyapatite, inhibitors, enhancers, specific amino acids and peptides and fatty acids.

The similar values found for Ca retention in relation to $\mathrm{N}$ retention in the milk diets suggested that protein level did not affect $\mathrm{Ca}$ availability. $\mathrm{Ca}$ in milk is found as complexes with casein, phosphate and citrate. Lactose in milk has been considered to be an enhancer for $\mathrm{Ca}$ availability in both rats (Armbrecht, 1987; Buchowski \& Miller, 1991) and man (Kabayashi et al. 1975; Cochet et al. 1983), although this has been questioned (Kocián et al. 1973; Behling \& Greger, 1990). It is suggested that the effect of lactose on $\mathrm{Ca}$ availability may vary depending on the source of $\mathrm{Ca}$ and the age of the individual (Buchowski \& Miller, 1991). Another explanation for the high $\mathrm{Ca}$ availability in milk has been ascribed to casein phosphopeptides, formed by degradation of casein (Hansen et al. 1997).

The values found for femur bone weight in relation to final weight were lower from the fish diets than from the milk diets. However, the fish diets appeared to be of good nutritional value to support growth in young rats. The high DM weight as well as ash content of the femur bones in all experimental diets reflected adequate uptake of $\mathrm{Ca}$ as well as other nutrients and optimal mineralization of the skeleton during growth. The similar Ca content in femur bones found in all rats reflected the fact that $\mathrm{Ca}$ was retained equally well in the femur bones from both fish and milk diets. The $\mathrm{Ca}: \mathrm{P}$ value observed was on average $1.58 \mathrm{~mol} / \mathrm{mol}$, suggesting that $\mathrm{Ca}$ and $\mathrm{P}$ in the femur bones existed in a mature hydroxyapatite lattice and skeletal growth was optimal from both fish and milk. The similar values found for bone AP in all rats suggested equal stimulation of bone formation at the end of the experimental period from both fish and milk.

It can be concluded that $\mathrm{Ca}$ from small fish with bones is available and appears to be a useful Ca source for growth in rats, although perhaps not as available as $\mathrm{Ca}$ from milk. The present study suggests that small fish with bones may be an important source of $\mathrm{Ca}$ in human diets. Reliable food consumption surveys as well as analyses of $\mathrm{Ca}$ in commonly consumed small fish species should be done to establish the 
intake of $\mathrm{Ca}$ from small fish. Also, Ca availability studies in human subjects over long periods of time, using mixed diets and taking into consideration traditional cooking methods, including the use of spices, should be conducted. Availability of $\mathrm{Ca}$ from small fish should be compared with that of green leafy vegetables, which are also commonly consumed and are major contributors to $\mathrm{Ca}$ intake. Small fish are an important commonly consumed food in many lowincome countries, as they are accessible, inexpensive, wellliked, culturally acceptable and can be purchased in small quantities. Thus, efforts should be made to promote the production as well as consumption of small fish which are eaten whole, especially in pregnant or lactating women and young children in low-income countries.

\section{Acknowledgements}

Financial support from the Bilateral Programme for the Enhancement of Research Capacity in Developing Countries (ENRECA), Ministry of Foreign Affairs, Denmark, through the project 'Food and nutrition security in Bangladesh: energy and micronutrients availability in rice based diets' is gratefully acknowledged.

\section{References}

Ahmad K \& Hassan N (1983) Nutrition Survey of Rural Bangladesh 1981-82. Dhaka: Institute of Nutrition and Food Science, University of Dhaka.

Allen LH (1982) Calcium bioavailability and absorption: a review. American Journal of Clinical Nutrition 35, 783-808.

Armbrecht HJ (1987) Age and the effects of lactose on the calcium and phosphorus uptake by rat small intestine. Nutrition Research 7, 1169-1177.

Behling AR \& Greger JL (1990) Importance of lactose in yoghurt for mineral utilization. Journal of Agricultural and Food Chemistry 38, 200-204.

Bowers GN \& McComb RB (1975) Measurement of total alkaline phosphatase activity in human serum. Clinical Chemistry 21, 1988-1995.

Bronner F (1987) Ca absorption. In Physiology of the Gastrointestinal Tract, vol. 2, pp. 1419-1435 [LR Johnson, editor]. New York, NY: Raven Press.

Buchowski MS \& Miller DD (1991) Lactose, calcium source and age affect calcium bioavailability in rats. Journal of Nutrition 121, 1746-1754.

Cochet B, Jung A, Griessen M, Bartholdi P, Schaller P \& Donath A (1983) Effects of lactose on intestinal calcium absorption in normal and lactase-deficient subjects. Gastroenterology $\mathbf{8 4}$, 935-940.

Darnton-Hill I, Hassan N, Karim R \& Duthie MR (1988) Tables of Nutrient Composition of Bangladesh Foods. English Version with Particular Emphasis on Vitamin A Content. Bangladesh: Helen Keller International.

Food and Agriculture Organization (1974) Handbook on Human Nutritional Requirements. Rome: FAO and WHO.

Gopalan C, Rama Sastri BV \& Balasubramanian SC (1987) Nutritive Value of Indian Foods. Hyderabad: National Institute of Nutrition.

Hansen M, Sandström B, Jensen M \& Sølvsten SS (1997) Casein phosphopeptides improve zinc and calcium absorption from rice-based but not from whole-grain infant cereal. Journal of Pediatric Gastroenterology and Nutrition 24, 56-62.

Heaney RP, Recker RR \& Weaver CM (1990) Absorbability of calcium sources: the limited role of solubility. Calcified Tissue International 46, 300-304.

Heaney RP, Weaver CM \& Recker RR (1988) Calcium absorbability from spinach. American Journal of Clinical Nutrition 47, 707-709.

Kabayashi A, Kawai S, Ohbe Y \& Nagashima Y (1975) Effects of dietary lactose and a lactase preparation on the intestinal absorption of calcium and magnesium in normal infants. American Journal of Clinical Nutrition 28, 681-683.

Kocián J, Skála I \& Bakos K (1973) Calcium absorption from milk and lactose-free milk in healthy subjects and patients with lactose intolerance. Digestion 9, 317-324.

Larsen T (1993) Dephytinization of a rat diet. Consequences for mineral and trace element absorption. Biological Trace Element Research 39, 55-71.

Larsen T \& Poulsen HD (1996) The relationship between mineral and nitrogen balances in growing pigs fed diets supplemented with zinc oxide. Canadian Journal of Animal Science 76, 409-415.

Larsen T \& Sandström B (1992) Effect of calcium, copper, and zinc levels in a rapeseed meal diet on mineral and trace element utilization in the rat. Biological Trace Element Research 35, 167-184.

Moss DW (1982) Alkaline phosphatase isoenzymes. Clinical Chemistry 28, 2007-2016.

Stuffins CB (1967) The determination of phosphate and $\mathrm{Ca}$ in feeding stuffs. Analyst 92, 107-111.

Wasserman RH \& Fullmer CS (1989) On the molecular mechanism of intestinal calcium transport. In Mineral Absorption in the Monogastric GI Tract, pp. 45-65 [FR Dintzis and JA Laszlo, editors]. New York, NY: Plenum Press.

Weaver CM, Martin BR, Ebner JS \& Krueger CA (1987) Oxalic acid decreases calcium absorption in rats. Journal of Nutrition 117, 1903-1906.

West CE \& Poortvliet EJ (1993) The Carotenoid Content of Foods with Special Reference to Developing Countries. Arlington, VA: International Science and Technology Institute, Inc. 